\title{
CONCEPTUAL PRINCIPLES OF VOCATIONAL TRAINING OF FUTURE PHYSICAL CULTURE TEACHERS FOR ORGANIZATION OF INDIVIDUAL WORK WITH PUPILS
}

\author{
Oleksandr Alieksieiev \\ Candidate of Pedagogical Sciences, Assistant Professor at the Department of Sport \\ and Sport Games, Kamianets-Podilskyi National Ivan Ohiienko University \\ Kamianets-Podilskyi, Ukraine \\ e-mail: alieksieiev@kpnu.edu.ua, orcid.org/0000-0002-6950-4413
}

\section{Summary}

The article deals with general characteristics of conceptual principles of vocational training of future physical culture teachers for organization of individual work with pupils. Given the specifics of pedagogy as a science, the pedagogical concept of vocational training of future physical culture teachers for organization of individual work with pupils, a complex, purposeful, dynamic system of fundamental knowledge about the pedagogical phenomenon, which fully and comprehensively reveals its essence, content, peculiarities, as well as the technology of its operation in modern education, has been defined. Structural imagination about the process of vocational training of future physical culture teachers for organization of individual work with pupils reflects directions of using basic principles of the concept and ensures its integrity, purposefulness and dynamism. The efficiency of implementation of the concept of vocational training of future physical culture teachers for organization of individual work with pupils depends on the precision of reproduction of its conceptual principles in educational process of the institutions of higher education. The concept of research contains a complex of key conceptual principles, which is considered as a combined, purposeful, dynamic set of theoretical-methodological and methodological-technological knowledge about theory and practice of vocational training of future physical culture teachers for organization of individual work with pupils, reflects the purpose, methods, means, scientific approaches, principles (general pedagogical and specific) and is based on the theoretical, methodological and practical concepts.

Keywords: concept, teachers, physical culture teachers, vocational education, theory, system.

DOI: https://doi.org/10.23856/4015

\section{Introduction}

Significant transformations, which take place in the field of school, vocational and pedagogical education, depend on the influence of different information streams, active and accelerated physical and intellectual development of youth, modern requirements to pedagogical staff of new generation. The main task of today's Ukrainian state policy is to create conditions for increasing the welfare of the population. Solving this problem correlates with the need to preserve and improve the health of citizens of all age groups, especially pupils of secondary schools.

After all, modern medical and biological studies of children's health show that school study is stressful, and in critical periods of adulthood is accompanied by reducing the adaptive capacities of the organism, developing different diseases, disorders of the visual organs and the cardiovascular system, neuropsychiatric disorders, disorders of the musculoskeletal system 
(posture distortion), etc. Such situation predetermines a necessity of the organization of physical activity of pupils at physical culture lessons, taking into account personal abilities of each schoolchild. At the same time, such change in strategy of physical culture lessons needs an appropriate level of teachers' readiness for organization of individual work with pupils.

Improvement of the process of vocational training of future teachers of that specialty in the direction of forming their own style of activity on the basis of using modern technologies at the physical culture lessons that needs concretization of conceptual foundations of this process.

The purpose of article is a general characteristic of conceptual principles of vocational training of future physical culture teachers for organization of individual work with pupils.

Methods of research. To gain the purpose a number of scientific cognition methods have been used, consistent application of which highlights the methodological strategy of the research. In particular, for the definitive analysis of categories of "concept", "conception" the methods of analysis, synthesis, comparison, and generalization have been used. In order to identify key conceptual provisions of the study the methods of abstraction, induction, deduction have been applied.

\section{Definitive analysis of key concepts}

Determining the conceptual principles of vocational training of future physical culture teachers for organization of individual work with pupils will allow unifying the developed author's information massive in order of further use of it in the educational process of the Ukrainian institutions of higher education (IHE). Within the research conceptual principles of vocational training of future physical culture teachers for organization of individual work with pupils will be considered as a list of requirements for the organization and provision of training for students of this specialty. On the one hand, the selected provisions characterize the integrity of the pedagogical process, and on the other hand, determine the conditions for ensuring high quality vocational training of future physical culture teachers for organization of individual work with pupils.

In order to avoid ambiguity in the interpretation of terms within the scientific investigation a definitive analysis of the concept of "principles" has been carried out. It should be noted that the definition of the context of using this category made it possible to find out that in the pedagogical literature the mentioned term is used in such meanings as: "rule", "factor", "aspect", 'condition", "fundamental reason", "justification", "substantiation”. It is worth noting that there is no single accepted interpretation of the term "principles".

In this study, the term "principles" will be understood as a set of externally determined and internally determined factors of the learning environment that help maximize the effectiveness of the process of training future physical education teachers for organization individual work with pupils. Whereas conceptual principles are a set of scientific knowledge about the theory and practice of training future teachers of this specialty.

Usually, the set of conceptual principles of the experimental study reflects a number of concepts. That is why we think it necessary to refer to the definition of the essence of the categories "concept" and "conception".

The definition of "concept" (from the Lat. conceptus - perception, content) is interpreted in classical philosophy as the act of "grasping" the meaning of the problem in the unity of speech (Kishchak, 2018). Scholars claim that the term was introduced into philosophy by P. Abeliar due to the analysis of the problem of universals, which, as well as the concept, involve the connection of things and speech about them, such as it is in the process of spelling that all possible meanings are conceived and the selection of a necessary meaning for a concrete demonstration is made (Titova, 2016). Perception of the concept as a phenomenon, which 
contains various meanings, is closed to the idea in its modern interpretation, where the concept is considered not just as a spoken or written word, but, above all, as the meanings, impressions, values that it actualizes (Brytskyi, Nesterov, 2016).

It should be mentioned that the concept, at the same time, is the unity of verbal expression, logically semantic component of semantic structure; characterizes the act of understanding and its result. In general, the concept is understood in science as existential-cultural, and not special-disciplinary formation; the main thing in the concept - "multidimensionality and discrete integrity of meaning", the ability to transmission from one subject area to another.

In the cognitive sciences, the concept refers to the basic unit of storage and transmission of information, which will structurally reflect the knowledge and experience of human. In scientific pedagogical knowledge, a certain order of minimum concepts forms a conceptual scheme, and finding the necessary concepts and establishing their relationship with each other reflects the essence of conceptualization. Concepts function inside of the formed conceptual scheme in the mode of understanding-explanation. Each concept takes its clearly defined and substantiated place at one level or another of the conceptual scheme. Concepts of one level may and should be specified at other levels, thus changing specific elements of the scheme. We should emphasize that concepts within one conceptual scheme do not necessarily have to be directly related to each other (but necessarily within the framework of the integrity in which they are included).

It should be mentioned that some concepts are rarely directly correlated with the corresponding subject branch. Rather, they are the means that organize in certain integrity the ways of seeing ("task", construction, constitution) of reality (under reality we mean the process of vocational training of future physical culture teachers for organization of individual work with pupils). In such sense some concepts have a certain ontological "fullness", which distinguishes them from constructs that represent only cognitive tools, use of which give the possibility to move from one level of theoretical work to another, and in this capacity may have no ontological "fullness". Through the schemes of conceptualization and operationalization, the existing concepts are generalized into systems of constructs that provide (ideally) their implementation and "derivation" to the empirical level of research. Concepts get personal interpretation in wider, purpose-level knowledge systems in relation to them, presenting them within a specific theory.

Taking into account the outlined theses, in order to achieve the maximum effectiveness of the study of vocational training of future physical culture teachers for organization of individual work with pupils, a number of concepts were identified, which we consider to be the methodological bases of scientific research. Such concepts are: provision of general systems theory; modeling as one of the most productive methods of studying and transforming systems; theory of humanistic personally oriented approach in study; theory and methods of vocational education; fundamental provisions on the unity of activity and personality as an active subject of activity and relations with the world; investigations that reveal the essence, content and structure of psychophysiological features of organization of individual physical activities of secondary school pupils at the physical culture lessons; normative-legal acts that control and regulate the process of physical education in secondary education institutions; the criteria and characteristics of pedagogical experiment as research method and other.

There is a though in science that some set of concepts reflects the essence of authors' conceptions. Conception (from the Lat. Conception - understanding, system) as a theoretical and methodological phenomenon in philosophy, linguistics, sociology have different definition 
is interpreted as: a system of views on something; the main thought; system of views, one or another understanding of phenomena, processes; the only defining idea, the leading idea of any composition, scientific work; a set of principles, which identify a direction of development and ways of solving tasks within a particular activity.

The analysis of definitions and philosophical approaches confirmed that the term "concept" is usually used in two main contexts: internal or external in relation to the process of studying the phenomenon, namely, as a guiding idea of research or as a form of presentation of the results of scientific work. In the last case, conception is a certain theoretical construction and that is why must have a clearly expressed logical structure. The most accurate in terms of goals and main purpose of our study is to understand the concept as a set of scientific knowledge about the object of research, designed in a special way.

Due to this fact we will adhere to the understanding of the conception as a complex of key provisions that fully and comprehensively reveal the essence, content and features of the studied phenomenon, its existence in reality or practical human activity (Veretelnikova, 2018). Given the specifics of pedagogy as a science, pedagogical conception of vocational training of future physical culture teachers for organization of individual work with pupils will be called a complex, purposeful, dynamic system of fundamental knowledge about pedagogical phenomenon, which fully and comprehensively reveals its essence, content, peculiarities and technology of their operation in the conditions of modern education.

\section{Characteristics of the pedagogical concept}

Let us reveal in more detail these characteristics of the pedagogical concept as a system of knowledge.

Complexity of theoretical knowledge reflects three main moments. First, the dialectical synthesis of key provisions that make up the various scientific theories that form the basis of the knowledge gained in the concept. Second, the diversity of the knowledge system and the connections between its parts. Third, the hierarchical structure of the concept as the system of knowledge that contains levels of subordination, which in turn determine the logic of the deployment of its general content: from general theoretical provisions to the technology of use in the educational process.

Purposefulness of the system of knowledge involves the definition, achievement and verification of a specific purpose as "ideal, imaginary prediction of activity results" (Bryk, 2016).

The main requirements for the purpose, according to the number of modern scholars, are:

- specificity - the description of results, which are expected to be achieved;

- measurability - the presence of appropriate measuring apparatus;

- reality - full availability of resources;

- controllability - the presence of information links that facilitate timely correction.

Dynamics of the system of knowledge mean some their relativity. Being closely related to the scientific movement as a whole, the author's conception as a point of view is not completely finished and is completely unchanged in the future. However, this does not mean the unreliability of the system of knowledge that makes up the concept, because in the main part they are justified and will not be refuted in the future, but only supplemented and adjusted.

Thus, the pedagogical concept as the result of scientific research is designed to ensure effective operation of the studied pedagogical phenomenon in modern education conditions. Hence the general functional purpose of the pedagogical concept of vocational training of future physical culture teachers for organization of individual works with pupils for the theory of pedagogy: 
- to synthesize individual knowledge about the process of vocational training of future physical culture teachers for organization of individual work with pupils into a single logic system;

- to explain significant characteristics, links, patterns of origin and development of readiness of future physical culture teachers for organization of individual work with pupils;

- to represent methodology of studying vocational training of future physical culture teachers for organization of individual work with pupils;

- to predict the prospects for the development of author's conception and to reveal the peculiarities of the factors of objective reality related to it;

- to propose practical methodical apparatus for the effective operation of the studied phenomenon (readiness of future physical culture teachers for organization of individual work with pupils).

\section{Structure of the author's conception}

The structural components of the conception are considered to be the main general conceptual idea, general provisions, principles, methodological bases and holistic view of the subject of the conception, directions of development and ways to solve the tasks within a particular activity.

Forming the author's pedagogical conception of vocational training of future physical culture teachers for organization of individual work with pupils provided for consideration and reliance on the principle positions that determine the next general minimum set of conceptual requirements: taking into account historical achievements of the theory of health saving and sports pedagogy in the process of studying and describing objective reality; contradictions as a source of development; solving contradictions as higher and more complex form of development. The analysis of the literature allowed us to identify the following successive stages in the construction of the conception, compliance with which logically reveals the essence of the process of overcoming the identified contradictions:

1) study and fixation of the initial forms of significant fragments of objective reality in their historical development;

2) definition and coordination of notions, which reflect these forms of development;

3) revealing contradictions in the definitions of notions and selection of significant contradictions among them;

4) search for a new, higher form of development of scientific knowledge, in which the recorded contradiction can be eliminated (Bytsiuk, 2017).

Applying to the scientific position of Ye. Yakovliev we assume that the author's pedagogical conception of vocational training of future physical culture teachers for organization of individual work with pupils as a system of scientific knowledge and scientific searching result, should contain the following structural components:

- general provisions, the content of which includes the notion of the conception, its purpose, legal and methodological support, limits of application, place in the theory of higher school pedagogy;

- conceptual and categorical apparatus, which demonstrates necessary in the study of definitions and relationships between them, providing unambiguity, logical "harmony" and provability of the presented conclusions;

- theoretical and methodological foundations, which includes methodological approaches for explaining the essence of studied process phenomenon that reflect interrelation of philosophical and concrete scientific knowledge and provide the necessary level of theorizing and substantiating the proposed conceptual provisions; 
- kernel, which contains general didactic and special patterns and principles and reflects the specifics of the process of training of future physical culture teachers for organization of individual work with pupils;

- content-semantic filling of the conception, which reflects practical sphere of activity of IHE instructors in the direction of formation of readiness of future physical culture teachers for organization of individual work with pupils;

- pedagogical conditions of formation of training of future physical culture teachers for organization of individual work with pupils;

- verification of conception, which will reflect the main provisions and specifics of organization of the pedagogical experiment to test and evaluate the effectiveness of the conception implementation as a whole.

\section{Conclusions}

Formation pedagogical conception of vocational training of future physical culture teachers for organization of individual work with pupils due to the proposed structure ensured its integrity, completeness and determined the complexity of the author's conclusions. At the same time it was taking into account that abandonment from any of the mentioned above components can lead to a violation of the logical "harmony" of the conception and the question of the prospects for its further use in pedagogical theory and practice.

Compositionally, the presentation of the pedagogical concept as a system of scientific knowledge and forms of presentation of research results includes: general provisions, conceptual and categorical apparatus, theoretical and methodological bases, kernel, content-semantic filling, pedagogical conditions of effective functioning and development of the studied phenomenon, verification.

Structural imagination about the process of vocational training of future physical culture teachers for organization of individual work with pupils reflects fields of using this conception and ensures its integrity, purposefulness and dynamism. The effectiveness of implementation of the concept of vocational training of future physical culture teachers for organization of individual work with pupils depends on accuracy of reproduction of its conceptual provisions in the educational process of IHE. All identified conceptual provisions are projected in order to form readiness of students of this specialty for organization of individual work with pupils at the physical culture lessons. The developed conception is the system of views at the problem of vocational training of future physical culture teachers for organization of individual work with pupils that takes into account its real state, socio-pedagogical preconditions and prospects of vocational training of students of this specialty.

The conception of research contains the complex of key provisions, is complex, focused, dynamic set of theoretical-methodological and methodological-technological knowledge of theory and practice of vocational training of future physical culture teachers for organization of individual work with pupils; reflects the purpose, methods, means, scientific approaches, principles (general pedagogical and specific) and is based on the theoretical, methodological and practical concepts.

The prospects of further studies in this direction are in separation and substantiation of pedagogical conditions of vocational training of future physical culture teachers for organization of individual work with pupils. 


\section{References}

Bytsiuk, V. V. (2017). Formuvannia profesiinoi subiektyvnosti fizychnoho vykhovannia yak problema fakhovoi pidhotovky [Formation of professional subjectivity of the teacher of physical leducation as a problem of vocationa ltraining]. Pedahohika formuvannia tvorchoi osobystosti $u$ vyshchii $i$ zahalnoosvitnii shkolakh - Pedagogy of formation of creative personality in higher and secondary schools, issue 56-57 (109-110), 75-82. [in Ukrainian]

Bryk, A. V. (2016). Vyznachennia vzaiemozviazkiv psykhomotornykh yakostei uchniv molodshykh klasiv na urokakh fizychnoi kultury [Determining the relationships of psychomotor qualities of elementary school pupils at physical training lessons]. Pedahohika formuvannia tvorchoi osobystosti $u$ vyshchii $i$ zahalnoosvitnii shkolakh - Pedagogy of formation of creative personality in higher andsecondary schools, issue 51 (104), 345-351. [in Ukrainian]

Veretelnikova, Yu. A., Nedorubko, S. A. \& Pavlenko, O. Ye. (2016). Pedahohichni inovatsii u fizychnomu vykhovanni studentiv [Pedagogical innovations in physical education of students]. Pedahohika formuvannia tvorchoi osobystosti u vyshchii i zahalnoosvitnii shkolakh - Pedagogy of formation of creative personality in higher and secondary schools, issue 51 (104), 419-427. [in Ukrainian]

Zakharina, Ye. A. (2018). Osoblyvosti profesiinoi pidhotovky maibutnikh fakhivtsiv z fizychnoi kultury i sportu do rekreatsiino ozdorovchoi diialnosti [Peculiarities of vocational training of futurespecialists in physical training and sports for recreational and health activities]. Pedahohika formuvannia tvorchoi osobystosti u vyshchii $i$ zahalnoosvitnii shkolakh - Pedagogy of formation of creative personality in higher and secondary schools, issue 58-59 (111-112), 344-349. [inUkrainian]

Kishchak, O. S. (2018). Formirovanie zdorovogo obraza zhizni studencheskoy molodezhi sredstvami fizicheskoy kultury [Formation of healthy lifestyle of student youth by means of physical culture]. Pedahohika formuvannia tvorchoi osobystosti u vyshchii i zahalnoosvitnii shkolakhPedagogy of formation of creative personality in higher and secondary schools, issue 58-59 (111-112), 368-372. [in Russian]

Rybnytskyi, A. V. \& Nesterov, O. S. (2016). Formuvannia zdorovoho sposobu zhyttia studentiv VNZ na zaniattiakh fizychnoho vykhovannia zasobamy fizkulturno-ozdorovchykh tekhnolohii [Formation of healthy lifestyle of HEI students at the classes of physical training by means of physical and fitness technologies]. Pedahohika formuvannia tvorchoi osobystosti u vyshchii $i$ zahalnoosvitnii shkolakh - Pedagogy of formation of creative personality in higher and secondary schools, issue 51 (104), 511-517. [inUkrainian]

Titova, H. (2017). Zmist metodyky pidhotovky maibutnikh uchyteliv fizychnoi kultury do formuvannia sportyvnykh liderskykh yakostei $v$ uchniv osnovnoi shkoly [The essence of methods of training of future teachers of physical culture for formation of sports leadership qualities among pupils of basis school]. Naukovyi visnyk Mykolaivskoho natsionalnoho universytetu imeni V. O. Sukhomlynskoho. Pedahohichni nauky - Scientific Bulletin of Mykolaiv V. O. Sukhomlynskyi National University. Pedagogical sciences, 4 (59), 523-528. [in Ukrainian] 